\title{
Colorectal Neuroendocrine Tumor pNO TNM Finding v8
}

National Cancer Institute

\section{Source}

National Cancer Institute. Colorectal Neuroendocrine Tumor pNO TNM Finding v8. NCI Thesaurus. Code C135181.

Colorectal neuroendocrine tumor without regional lymph node metastasis. (from AJCC 8th Ed.) 